\title{
KAJAN MATAN DAN SYARAH HADIS TENTANG WAJIB MANDI BAGI PEREMPUAN YANG MIMPI BASAH
}

\author{
Ana Cahayani Fatimah \\ STIT Sunan Giri Bima NTB \\ Email: anacahayanigmail.com
}

\begin{abstract}
This article examines the traditions and traditions of traditions through the narration of Ahmad Bin Hanbal, it is found that the quality of traditions in terms of quality and traditions is authentic. and In the proposition of men and women who dreamed wet and then issued a semen, then he must take a shower. Conversely, if you do not issue semen, then you are not obliged to take a shower, because the reference for the bath is the discharge of the semen, not the dream. And if understanding and practicing the argument about compulsory bathing for women who have a wet dream will get a reward because Mandi Junub according to Shari'a is an obligation as the Word of the Prophet Muhammad, narrated by Abu Malik Al Asy'ari. The Messenger of God, may God bless him and grant him peace, said: Purification is part of faith (Narrated by Muslim) "Sanctity (cleanliness) is part of faith. while carrying out religious orders correctly according to the rules of Allah swt. which is contained in the Al-Qur'an and As-sunnah is given reward reward.
\end{abstract}

\section{Keywords: Hadith Study, Mandatory Bathing, Wet Dreams}

\begin{abstract}
ABSTRAK
Artikel ini mengkaji sanad dan matan hadis melalui periwayatan Ahmad Bin Hanbal, ditemukan bahwa kualitas hadis dilihat dari segi sanad dan matannya berkualitas shahih. dan Secara dalil lelaki maupun wanita yang mimpi basah kemudian mengeluarkan mani maka dia wajib mandi. Sebaliknya, jika tidak mengeluarkan mani maka tidak wajib mandi, karena yang menjadi acuan mandinya adalah keluarnya mani, bukan mimpinya. Dan apabila memahami dan mempraktekkan dalil tentang wajib mandi bagi perempuan yang mimpi basah maka akan mendapatkan pahala karana Mandi Junub secara syariat adalah kewajiban sebagaimana Sabda Rَالَ رَسُولُ اللَّهِ "Kesucian (kebersihan) adalah bagian dari iman. sedangkan menjalankan perintah agama dengan benar sesuai tata aturan Allah swt. yang termuat dalam Al-Qur'an dan As-sunnah makan diberikann ganjaran pahala.
\end{abstract}

Kata Kunci : Kajian hadis, Wajib Mandi, Mimpi Basah

\section{PENDAHULUAN}

Mandi junub ialah mandi yang diwajibkan oleh agama Islam atas orang orang mukalaf dari kalangan pria maupun wanita untuk membersihkan diri dari hadats besar. Dan menurut aturan Syari'at Islamiyah, mandi junub itu dinamakan mandi wajib dengan mengalirkan air ke seluruh bagian tubuh. Mandi junub ini adalah termasuk dari perkara syarat sahnya shalat, sehingga bila tidak mengerjakannya dengan cara yang benar 
maka mandi junub itu tidak dianggap sah sehingga masih belum lepas dari hadats besar. Akibatnya shalat dianggap tidak sah bila menunaikannya dalam keadaan belum bersih dari hadats besar dan kecil. Sedangkan mandi junub yang benar itu ialah mandi junub yang dilakukan dengan mengamalkan car-cara mandi junub yang diajarkan oleh Nabi Muhammad sallallahu alaihi wa aalihi wasallam.

Kedudukan Hadis sebagai sumber hukum pada urutan kedua setelah al-Qur'an dengan fungsi sebagai penjelasan (al-bayan) terhadap kandungan isi al-Qur'an, dipahami bahwa dari segi periwayatan Hadis berbeda dengan al-Qur'an bersifat qath'i al-wurud yakni kedatangan dan penetapannya menimbulkan keyakinan yang pasti kebenarannya, sedangkan Hadis bersifat Zhanni al wurud yang berarti kedatangan dan penetapannya tidak menimbulkan keyakinan yang pasti kebenarannya ${ }^{1}$ Berdasarkan fungsi dan kedudukan hadis yang demikian ini, menunjukkan betapa pentingnya penelitian terhadapnya untuk mengetahui kualitas keshahihan atau kedhaifan suatu hadis.

Untuk itu tujuan penulisan artikel ini adalah dalam rangka mengungkap kualitas

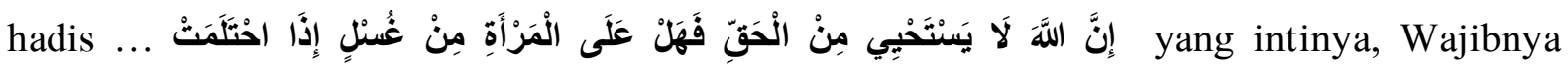
Perempuan Mandi Junub Apabila Bermimpi Basah?

\section{METODE PENELITIAN}

Jenis penelitian yang digunakan dalam riset ini adalah kepustakaan (Library Research). Dalam hal ini penulis menggunakan pendekatan normatif deskriptif yang menekankan pada analisis sumber-sumber data yang ditemukan. studi kepustakaan merupakan segala usaha yang dilakukan oleh peneliti untuk menghimpun informasi yang relevan dengan topik atau masalah yang akan atau sedang diteliti. Informasi itu dapat diperoleh dari buku-buku ilmiah, laporanpenelitian, karangan-karangan ilmiah, tesis, disertasi,peraturan-peraturan, ketetapan-ketetapan, kitab Suci, kitab-kitab Hadis,buku tahunan, ensiklopedia, kitab-kitab tafsir dan sumber-sumber tertulis lain baik elektronik maupun cetak.

\section{Takhrij Hadis dan Ittibar Sanad Hadis}

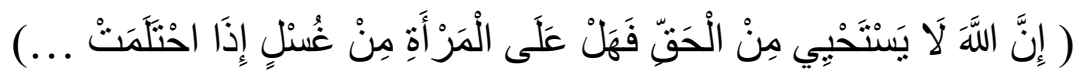

Berdasarkan petunjuk al-Mu'jam al-Mufahras al-Nabawiy, diperoleh data bahwa hadis tentang Wajibnya Perempuan Mandi Junub Apabila Bermimpi Basah, terdapat dalam beberapa kitab rujukan sebagai berikut:

1. Al-Bukhariy dalam al-Shahih ada di empat tempat

${ }^{1}$ Shalah al-Din Ahmad al-Adhabi, Manhaj al-Naql al-Matn al-Hadis, (Cet. II; Kairo: Dar al-Afaq alJadidah, 1983), h. 239. 
a. Kitab al-'Ilm, bab al-Haya' Fi al-'Ilm, No. 127.

b. Kitab al-Ghusli, bab Idza Ihtalamat al-Mar'ah no.273.

c. Kitab, Ahadits al- Anbiya' bab bab, Khalaq Adam wa Dzurriyatih, 3081.

d. Kitab al-Adab bab Ma La Yustahyi Nin al-Haqq, no. 5656.

2. Muslim dalam al- Shahih Kitab al-Haidh bab Wujub al-Ghusl 'Ala al-Mar'ah no. 471 ada ada satu tempat.

3. Al-Tirmidzi dalam al-Sunan ada satu jalur, Kitab al-Thahharah, bab Ma Ja'a Fi alMar'ah Tara Fi al-Manam no. 113

4. Al-Nasa'iy dalam al-Sunan ada dua jalur Kitab al-Thahharah, bab al-Ghusl Tara alMar'ah Fi Manamiha Ma Yara al-Rajul no. 196, 197

5. Ahmad bin Hanbal dalam al-Musnad Kitab Baqy Musnad al-Anshar, no. 25295, 25367,25865

6. Kitab Malik dalam al-Mu'atha' Kitab al-Thahharah, bab Ghusl al-Mar'ah Ra'at Fi al-Manam, no. 106

7. Al-Dārimiy, dalam al-Sunan Kitab al-Thahharah bab al-Ghusl Tara al-Mar'ah Fi Manamiha Ma Yara al-Rajul no. 756 . $^{2}$

Dengan demikian, dapat diketahui bahwa hadis tersebut diriwayatkan oleh tujuh orang al-Mukharrij, yakni al-Bukhariy dalam kitab Shahih-nya ada pada empat tempat, Muslim dalam kitab Shahih-nya ada satu tempat, al-Nasaiy dalam kitab Sunan-nya ada pada satu tempat, Ahmad bin Hanbal dalam al-Musnad Kitab al-Thahharah, Imam Malik dalam kitab al-Mu'attha'ada dalam satu tempat dan Imam al-Darimiy dalam Sunan-nya ada dalam satu tempat. Olehnya itu hadis tersebut dapat dinyatakan akhrijahu al-Sab'ah dengan 14 jalur sanad dan sahabat yang meriwayatkan dari Nabi ada enam yaitu, Aba Salamah, Ummi Salamah, Ummi Sualim, Zainab binti Aba Salamah dan Aisyah.

Adapun susunan sanad dan matan hadis yang dimaksud adalah sebagai berikut:

1. Bukhari dalam al-Shahih ada empat jalur ${ }^{3}$

a. Kitab al-'Ilm bab al-Haya' Fi al-'Ilm, No. 127

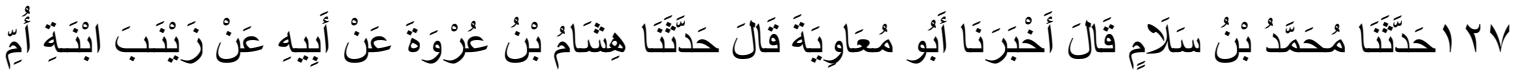

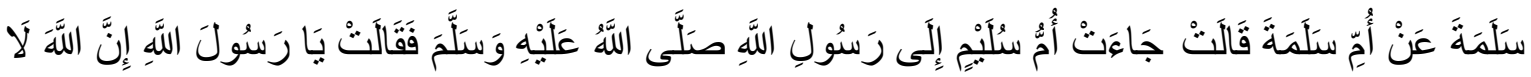

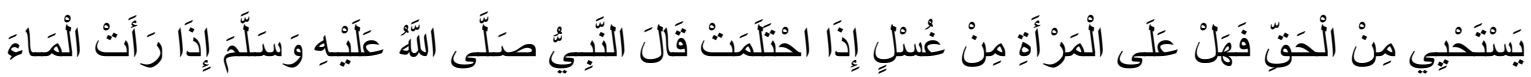

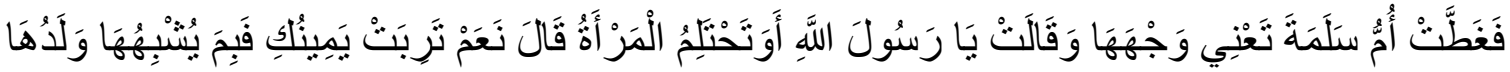

Terjemahnya :

Telah menceritakan kepada kami Muhammad bin Salam berkata, telah mengabarkan kepada kami Abu Mu'awiyah berkata, telah menceritakan kepada kami Hisyam bin 'Urwah dari Bapaknya dari Zainab puteri Ummu Salamah, dari Ummu Salamah ia berkata, "Ummu Sulaim datang menemui Rasulullah shallallahu 'alaihi wasallam dan berkata, "Wahai Rasulullah, sesungguhnya Allah tidak malu dalam perkara yang hak. Apakah bagi wanita wajib mandi jika ia bermimpi?" Nabi shallallahu 'alaihi wasallam menjawab: "Ya, jika dia melihat air." Ummu Salamah lalu menutupi wajahnya seraya

${ }^{2}$ Arnold John Wensinck, et, al, Concordance et Indices De Ela Tradition Musulmane, diterjemahkan ke dalam bahasa Arab oleh Muhammad Abd. Fu'ad Baqy, dengan judul al-Mu'jam al-Mufahras Li alfazh alHadits al-Nabawi, Jilid. I ( Leiden, E. J. Brill, 1946), h. 227.

${ }^{3}$ Al-Imam Abiy 'Abdillah Muhammad bin Isma'il bin Ibrahim bin Mughirah bin Bardizbah alBukhari al-Ju'fiy, Juz. I, V , ( Semarang, Karya Toha Putera, tt ), h. 3-4, 85. 
bertanya, "Wahai Rasulullah, apakah seorang wanita itu bermimpi?" Beliau menjawab: "Ya. Celaka kamu. (jika tidak) Lantas dari mana datangnya kemiripan seorang anak itu?"

b. Kitab al-Ghusli bab Idza Ihtalamat al-Mar'ah no.273

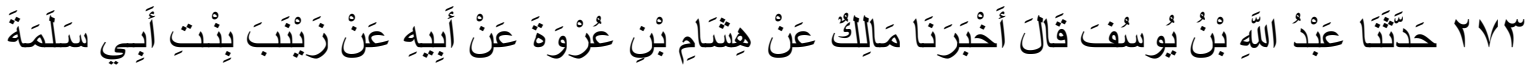

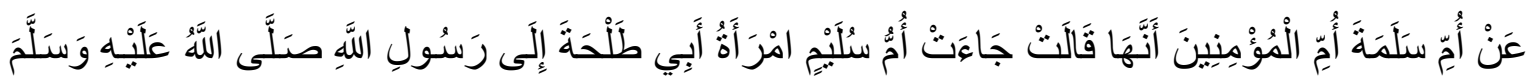

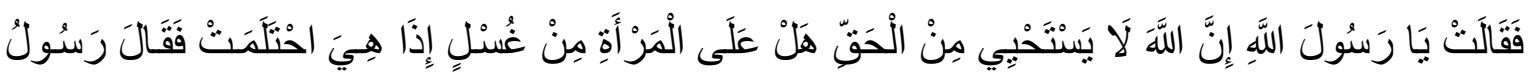

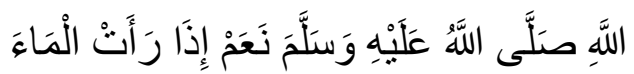

c. Kitab Ahadits al-Anbiya'no. 3081

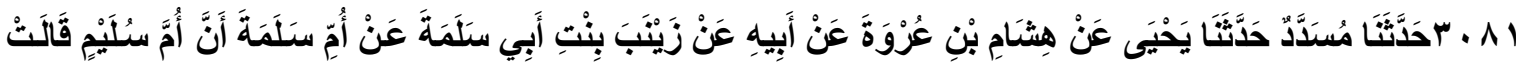

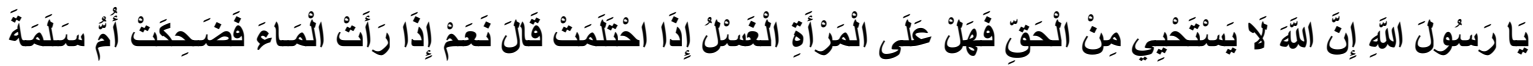

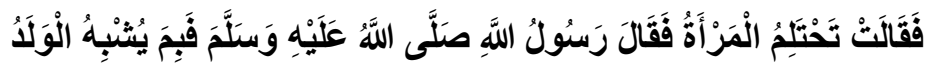

d. Kitab al-Adab no. 5656

104 104

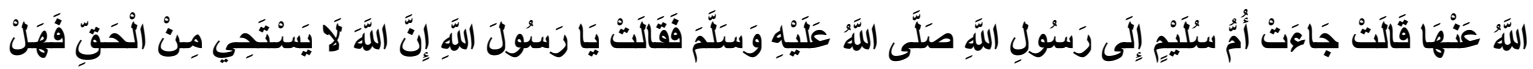

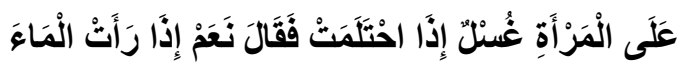

2. Muslim dalam al-Shahih Kitab al-Haidh bab Wujub al-Ghusl 'Ala al-Mar'ah ada ada satu jalur ${ }^{4}$

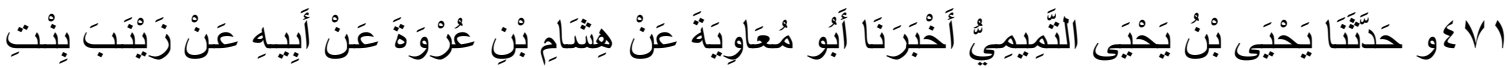

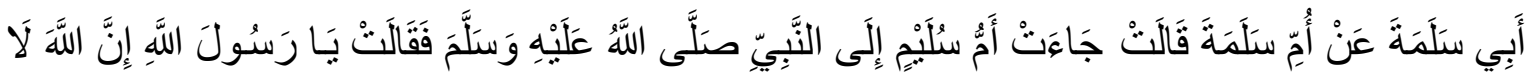

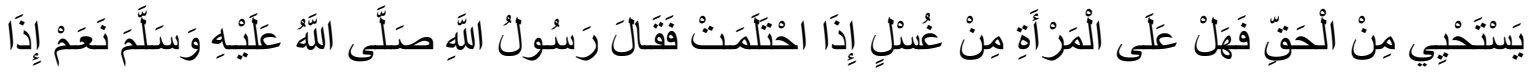

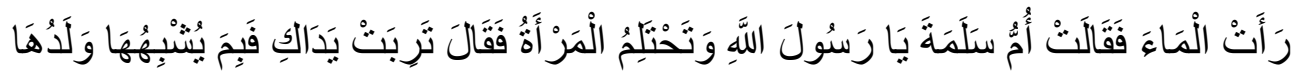

3. Al-Tirmidzi dalam al-Sunan Kitab al-Thahharah Ma Ja'a Fi al-Mar'ah Tara Fi al-

Manam ada satu jalur ${ }^{5}$

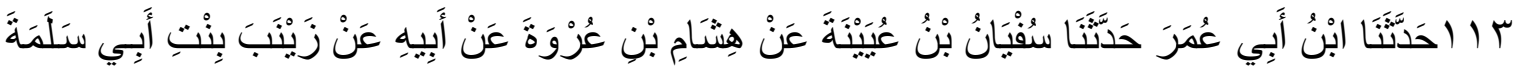

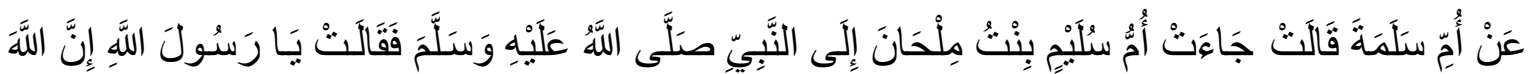

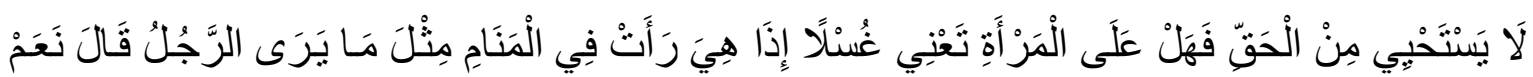

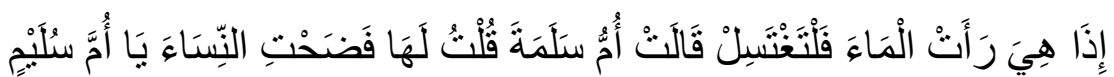

4. Al-Nasa'iy dalam al-Sunan Kitab Kitab al-Thahharah, bab al-Ghusl Tara al-Mar'ah Fi Manamiha Ma Yara al-Rajul ada dua jalur ${ }^{6}$

${ }^{4}$ Muhammad Fu'ad ‘Abdu al-Baqy, Shahih Muslim, Juz. II ( Beirut, al-Ahyar al-Tarits al-‘Arabiy).

5 Abi 'Aisay Muhammad ibn Aisay ibn Surah al-Tarmizy, Sunan al-Tarmizy, (Beirut-Libanon, Dar alKotob al-Ilmiyah, 2003M-1324H), h. 636.

${ }^{6}$ Al-Hafizh Jalauddin al-Suyuti, Sunan al-Nasa'iy, (Beirut Dar al-Kitab al-Araby, tt), h.34, 49, $124-$ $125,175-176$. 
197

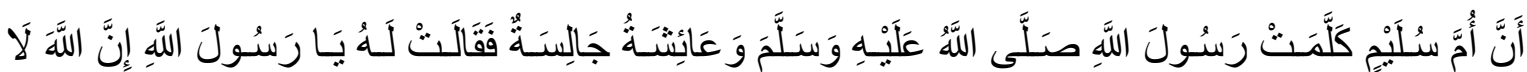

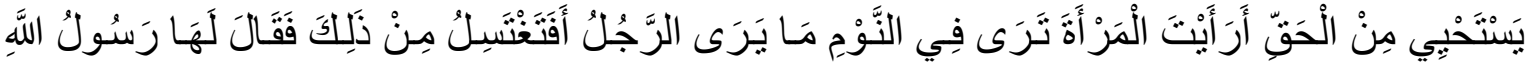

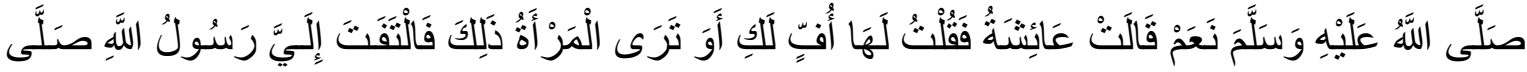

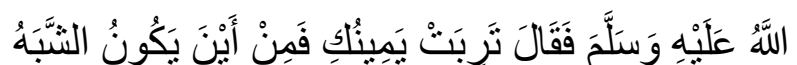

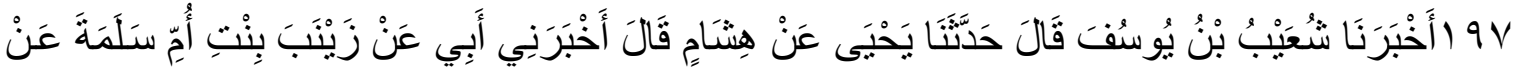

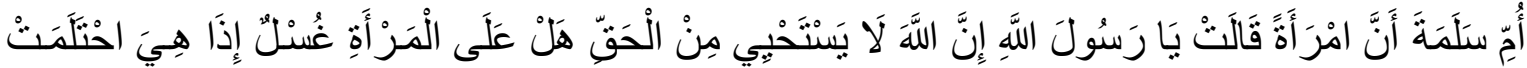

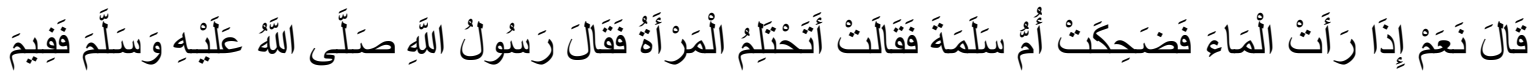

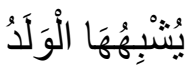

5. Ahmad bin Hanbal dalam al-Musnad Kitab Baqy Musnad al-Anshar, ada satu jalur ${ }^{7}$

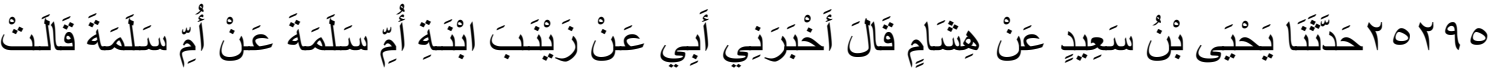

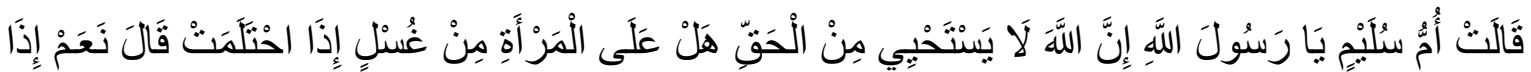

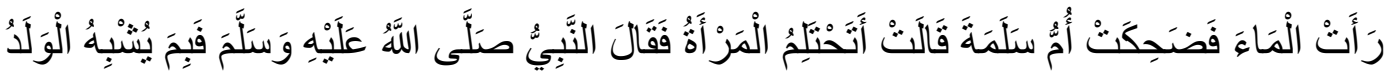
عَالِ

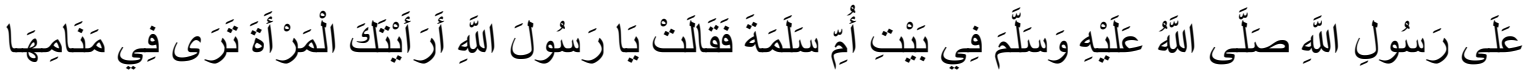

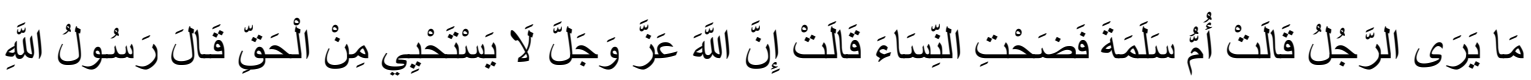

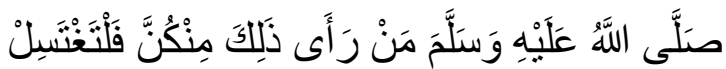

Terjemahnya :

Telah menceritakan kepada kami Ibnu Numair dia berkata, telah menceritakan kepada kami Muhammad -yakni Ibnu 'Amru- dia berkata, telah menceritakan kepada kami Abu Salamah dari Ummu Sulaim dia berkata, "Aku menemui Rasulullah shallallahu 'alaihi wasallam di rumah Ummu Salamah, dia berkata, "Wahai Rasulullah, bagaimana jika wanita bermimpi seperti apa yang dimimpikan lelaki?" Ummu Salamah berkata, "Kamu telah membuka aib wanita." Ummu Sulaim berkata, "Sesungguhnya Allah Azza wa Jalla tidak malu kepada kebenaran." Rasulullah shallallahu 'alaihi wasallam lalu bersabda: "Jika salah seorang dari kalian bermimpi seperti itu maka mandilah."

6. Kitab Malik dalam al-Mu'atha' Kitab al-Thahharah, bab Ghusl al-Mar'ah Ra'at Fi al-Manam, ada satu jalur ${ }^{8}$

${ }^{7}$ Lil-Imam Ahmad bin Hanbal, Syarah Hamzah Ahmad Zain, Musnad Ahmad bin Hanbal, Juz. 7, 8, 9 (al-Qahirah, Dar al-Hadits, 1999), h. 366, 513-514.

${ }^{8}$ Shiddiqiy Jamil al-‘Atthar, al-Mu'attha'(Beirut Dar-al-KOTTOB, 2002), h.450-451. 


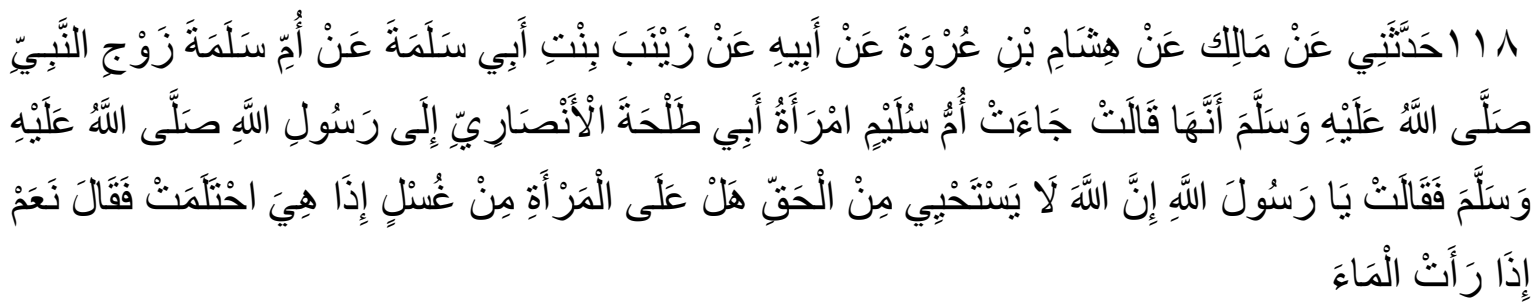

7. al-Darimi dalam al-Sunan Kitab al-Thahharah bab al-Ghusl Tara al-Mar'ah Fi Manamiha Ma Yara al-Rajul ada satu jalur ${ }^{9}$

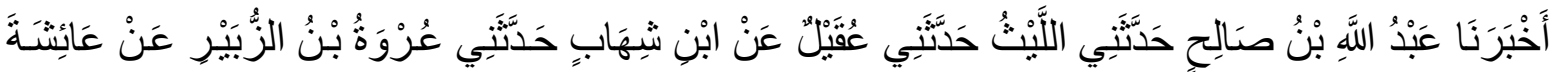

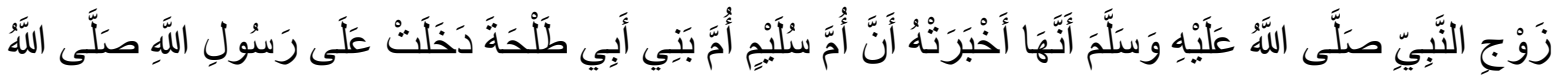

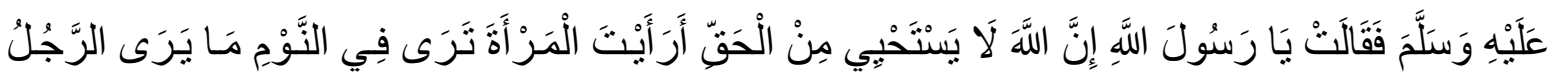

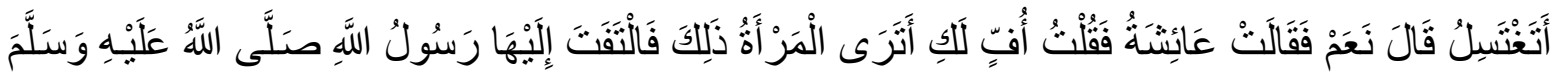

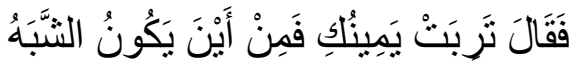

Dari teks hadis di atas, tampak jelas memiliki jalur sanad yang bervariasi, baik nama penyampai periwayatnya kepada Mukharrij, juga lambang atau shighat tahammul (صنا ( تحندـ yang digunakan. Dengan demikian maka wajar apabila diadakan kritik sanad, terutama bagi mereka yang menggunakan lambang معن عنـة ) عن sebab pengguna $m u$ 'an 'anah itu, pada dasarnya sanadnya tidak bersambung kecuali para sahabat dan perawi yang berstatus tsiqah ( 'adil, dhabit / kepercayaan). Sebab ulama menyatakan bahwa para periwayat itu tidak mungkin berbohong dalam ucapannya, apalagi yang disampaikan itu hadis Nabi

Untuk mengetahui lebih lanjut tentang perawi hadis yang terlibat di dalam rangkaian sanad hadis yang telah ditakhrij maka selanjutnya adalah melakukan I'tibar al-sanad, ${ }^{10}$ yakni menyertakan sanad-sanad hadis yang lain untuk suatu hadis sehingga ditemukan metode periwayatan yang digunakan periwayat hadis yang berstatus mutabi'i dan syahid atas hadis tersebut.

\section{I'tibar al-Sanad}

Mengenai kegunaan al- I'tibar, maka H. M. Arief Halim menjelaskan bahwa dengan kegunaan I'tibar selain untuk mengetahui keadaan sanad hadis seluruhnya dilihat dari segi pendukung ada atau tidak adanya pendukung (corroboration) dalam bentuk mutabi', atau syahid, juga untuk mengetahui keadaan persambungan setiap sanad sampai kepada Nabi

\footnotetext{
${ }^{9}$ Abu Abdillah bin Abd. al-Rahman bin al-Tamimiy al-Dzarimiy, Sunan al-Darimi al-Samarqaniy, Juz. I ( Bandung, Dahlan, $\mathrm{tt}$ ).

${ }^{10} \mathrm{M}$. Syuhudi Ismail,op,cit,h. 51-52.
} 
Muhammad saw, dan dari sini juga akan dapat diketahui bahwa hadis yang dikaji itu berstatus mutawatir atau hadis ahad. ${ }^{11}$

Untuk memperjelas dan mempermudah kegiatan i'tibar, maka diperlukan pembuatan skema untuk seluruh hadis yang akan dikaji. Dalam skema itu, akan tampak garis-garis yang menghubungkan jalur-jalur antara periwayat yang satu dengan yang lainnya. Dan akan tampak ada tidaknya muttabi, ( pendukung) bagi periwayat yang dikritik oleh ulama tentang ketsiqahan nya. Berkenaan dengan itu berikut ini digambarkan skema sanad hadis yang dikaji, yakni:

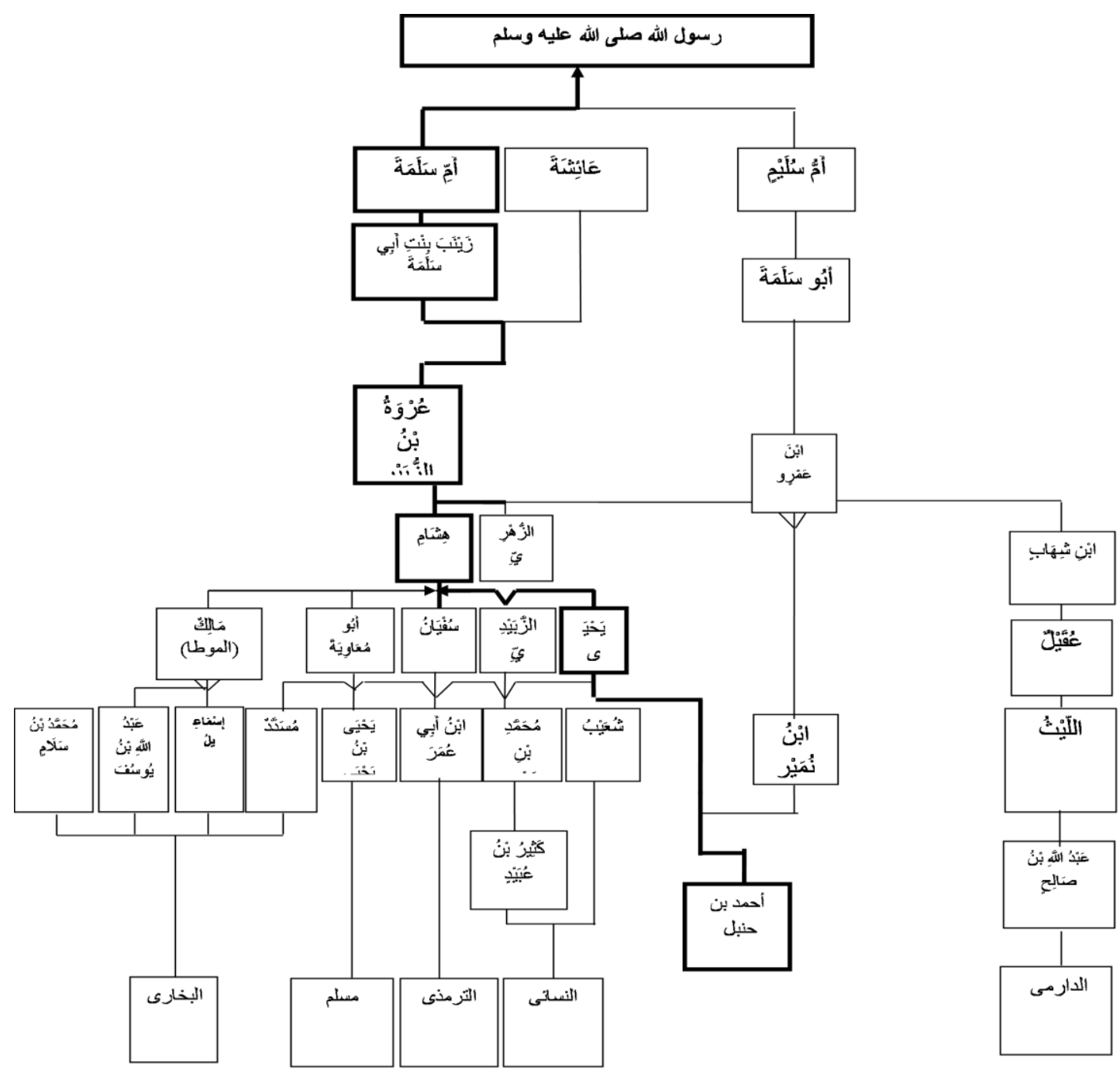

${ }^{11}$ M. Arief Halim, Metodeologi Tahqiq Hadith Secara Mudah dan Munasabah, (Pulau Penang: Univesrsity Sains Malaysia, 2007), h. 47. 
Berdasarkan skema tersebut diketahui bahwa pada hadis di atas terdapat syahid, Yaitu Abu Salamah, Ummu Salamah, Zainab binti Abu Salamah dan Aisyah menyaksikan langsung Ummu Sulaim, (sahabat Nabi Saw) berkedudukan sebagai tabaqah pertama yang menyaksikan awal disabdakannya hadis tentang apakah perempuan itu mandi junub apabila bermimpi basah.

Pada skema di atas juga diketahui bahwa sighat al-tahammul ada al-hadits yang digunakan perawi hadis bervariasi, yakni haddatsana, waqala, akhbarana, anbana, tsana dan an. Ini menunjukkan bahwa perawi hadis menggunakan metode yang berbeda-beda, demikian pula bila dicermati dari urutan sanad dan periwayatan yang menunjukkan bahwa sanad terakhir hadis ini adalah tingkat sahabat menyandarkan pada perkataan Rasulullah Saw., maka hadis ini dapat digolongkan sebagai hadis marfu'.

\section{Penelitian Sanad dan Matan Hadis}

Berdasarkan kegiatan takhrij dan i'tibar diperoleh data yang menunjukkan bahwa terdapat beberapa jumlah jalur sanad, untuk efesiensi dipilih salah satu sanad untuk diteliti secara cermat. Jalur yang dipilih adalah jalur Ahmad bin Hanbal dari Yahya bin Sa'id karena Ahmad bin Hanbal berada di rangking ketujuh setelah Bukhari dan Muslim yang menunjukan urutan periwayat dan sanad sebagai berikut :

1. Ahmad bin Hanbal

Nama lengkap Abu Abdillah bin Muhammad bin Hanbal al-Marwazy nama kuniyah Ahmad bin Hanbal, berdomisili Bagdad. Wafat di Bagdad pada tahun $241 \mathrm{H}$. Beliau juga seorang pelopor dalam sejarah Islam yang mengkombinasikan antara ilmu hadis dan fiqh. ${ }^{12}$ Ahmad bin Hanbal mendapatkan guru kenamaan, antara lain; Sufyan bin Uyainah, Ibrahim bin Sa'd, Yahya bin Waththan dan Muhammad bin Ja'far. Muridnya. Adapun ulama besar yang pernah mengambil ilmu darinya antara lain Imam Bukhari, Imam Muslim, Abu Dawud, Ibnu Abi al-Dunya dan Ahmad bin Abi al-Hawarimy. Beliau sendiri adalah seorang murid Syafi 'i yang paling setia.

Komentar Ulama Hadis terhadap ke-tsiqahan-nya, adalah para ulama telah bersepakat bahwa Ahmad bin Hambal adalah sebagai al-Mukharrij al-Hadis tidak diragukan lagi kredibilitas pribadinya. Berdasarkan komentar para ulama hadis tersebut dapat dinyatakan bahwa sanad antara Ahmad bin Hanbal dan Yahya bin Sa'id adalah mutashil. (bersambung).

${ }^{12}$ Mustafa al-Azami, Dirasah fi al-Hadis al-Nabawi; Tarikh tadwinihi, (Riyad, Jamiah Riyad, tt), h. 45. 


\section{Yahya bin Sa'id}

Yahya bin Sa'id nama lengkapnya adalah Yahya bin Sa'id bin Farwah, mempunyai julukan (kunyah) Abu Sa'id, nama panggilannya (Alqab) al-Ahwal termasuk kelompok ulama al-Shaghir min al-Itba', menetap di Bashrah dan wafat di Bashrah pada tahun $198 \mathrm{H}$.

Gurunya antara lain, Ibnu Abi Sum'ah, Ibnu bin abdillah bin Abi Hazm, Ibnu bin Yazid, Ibrahim bin Ismail bin Majma' Ibrahim bin al-Fadhl, Abu Amr bin al-'Ala', Idris bin Yazid bin abd. al-Rahman, Usamah bin Zaid bin Aslam, Ishaq bin Sa'id bin Amr, Israil bin Yunus, Ismail bin Ibrahim, Ismail bin Rafi' Asy'ats bin Sa'id dan Hisyam bin Urwah.

Muridnya antara lain Ibrahim bin Ishaq bin Isa, Ibrahim bin Musa bin Yazid, Ahmad bin Abdullah bin Abi Syu'aib, Ahmad bin Muhammad bin Tsabit, Ahmad bin Muhammad bin 'Ubaidillah, Ahmad bin Muhammad bin Hanbal bin Hilal bin Asad, Ahmad bin Mani', Ishaq bin Ismail, Ishaq bin Ibrahim bin Makhlad, al-Jarud bin Sa'd, Hijab bin Sulaiman, alHasan bin Ali bin Muhammad, Ali bin Muhammad dan Abu Bakar bin Abi Syaibah,

Penilaian ulama hadis terhadap kredibilatas ketsiqahan Yahya bin Sa'id' adalah: Ahmad bin Hanbal menyatakan bahwa Yahya bin Sa'id adalah orang yang bayak ilmunya dan tidak ada yang membandingi hafalannya, Yahya bin Ma'in berkata bahwa Yahya bin Sa'id' adalah seorang yang hafizh, Al'ajaliy berkata bahwa Yahya bin Sa'id' adalah seorang yang tsiqah min hafizh al-Hadits, sementara Muhammad bin Sa'd menyatakan bahwa Yahya bin Sa'id' adalah seorang yang tsiqah ma'mun hujjah, dan Ibnu Hibban berkata bahwa Yahya bin Sa'id' adalah hafizh muttaqin.

Berdasarkan pernyataan para ulama hadits di atas dapat disimpulkan bahwa Yahya bin Sa'id' adalah seorang yang tsiqah hafizh. Olehnya itu dapat dinyatakan bahwa sanad antara Yahya bin Sa'id' dan Hisyam adalah mutashil (bersambung).

3. Hisyam

Hisyam bin Urwah yang bernama lengkap Hisyam bin urwah bin al-Zubair bin alAwwam dan julukannya (kunyah) adalah Abu al-Mundzir, menetap di Madinad dan wafat di Bagdad pada tahun $145 \mathrm{H}$ beliau termasuk ulama al-Shaghir min al-Tabi'in. Guru-gurunya banyak dari kalangan Shahabat dan Tabi'in antara lain adalah, Aisyah bin Abu Bakar alShiddiq, Abd. al-Rahman bin al-Qasim bin Muhammad bin abu Bakr al-Shiddiq, abdi bin abdillah bin al-Zubair bin al-Awwam, Abd. al-Rahman bin Sa'd, Bakar bin Wail bin Dawud, al-Husain bin Abdullah bin Ubaidillah bin 'Abbas, Hafshah binti Sirrin, Zubaid bin Shalt bin Ma'dikarib, Shalih bin Abi Shalih, Shalih bin Abi Rabi'ah bin al-Hidir, Abdullah bin Abi Bakr bin Muhammad bin Amr, Abdullah bin Abd. al-Rahman bin 'Auf, Abdullah bin alZubair bin Awwam dan Urwah bin al-Zubair. Muridnya antara lain adalah Ibrahim bin Hamid bin Abd. al-Rahman, Ibnu bin Yazid, Ibrahim bin Sa'd, Abu Bakar bin 'Isya bin 
Salim, Usamah bin Hafsh, Israil bin Yunus, Anas bin Iyadh bin Dhamrah, Ayub bin Abi Tamimah, Jarir bin Hazm, Jarir bin Abd. al-Hamid, Ja'far bin Sulaiman, Junadah bin Salam bin Khalid, al-Harits bin Imran, Hajaj bin Arthah bin Tsawr, dan Waki'

Pernyataan ulama hadits terhadap kredibilitas pribadi Hisyam bin Urwah adalah, Muhammad bin Sa'd berkata bahwa Hisyam bin Urwah adalah seorang tsiqah tsubut hujjah, Ya'kub bin Abi syaibah menyatkan bahwa Hisyam bin Urwah adalah tsiqah tsubut, sementara Abu Hatim al-Raziy berkata bahwa Hisyam adalah tsiqah Imam fi al-Hadits, Ibnu Kharsy berkata bahwa Hisyam bin Urwah adalah shaduq, al-'Ajaliy menyatakan bahwa Hisyam adalah seorang yang tsiqah dan Ibnu Hibban mengatakan bahwa Hisyam adalah muttaqin. Berdasarkan pernyataan ulama hadits di atas bahwa Hisyam adalah seorang yang tsiqah, Imam, tsubut, kadang-kadang yudallis,(menyembunyikan gurunya yang kurang kuat). Olehnya itu dapat disimpulkan bahwa sanad antara Hisyam dan Urwah adalah mutashil (bersambung).

\section{Urwah bin al-Zubair}

Urwah, nama lengkapnya adalah Urwah ibn al-Zubair ibn al-Awwam ibn Khuwailid, ibn Asad, berdomisili di Madinah, wafat pada tahun $93 \mathrm{H}$. gurunya banayak dari kalangan sahabat yaitu di antaranya : Usmah ibn Zaid ibn Haritsah, Asma' binti Abu Bakar alShiddiq, Asma' binti Umais, Basyir ibn Abi Mas'ud ibn Uqbah, Jabir ibn Abdullah, Hamzah ibn al-mughirah, Hafshah binti Jahsyn dan Aisyah binti Abu Bakar al-Shiddiq. Muridnya adalah : Abu Bakr ibn Abdullah, Ismail ibn Hakim, Tamim ibn Salamah dan Ibni Syihab. adapun penilaian ulama Hadis terhadap ke-tsiqahan-nya adalah sebagai berikut. Menurut Ibnu Hibban bahwa Urwah adalah seorang yang tsiqah. Sementara Ibnu Qani' berkata, bahwa Urwah adalah seorang yang tsiqah, shalih, dan al-Dzahabi menyatakan tsiqah. Berdasarkan pernyatan para ulama hadits di atas dapat disimpulkan bahwa Urwah adalah seorang yang tsiqah. Olehnya itu bahwa pernyataannya bahwa ia telah menerima hadits dari Zainab binti abu Salamah adalah dapat dipercaya dan sanad antara Urwah dan Zainab adalah bersambung.

\section{Zainab binti Abi Salamah}

Zainab binti Abi Salamah nama lengkapnya adalah Zainab binti Abi Salamah bin Abd. al-Asad adalah Shabat Rasulullah Saw. Menetap di Madinah dan wafat pada tahun $73 \mathrm{H}$. Guru-gurnya antara lain, Habibah binti Ubaidillah bin Jahsy, Hamnah binti Jahsy, Ramlah binti Abi Sufyan, Zainab binti Jahsy, Aisyah binti Abi Bakar al-Siddiq, Hindun binti Abi Umayyah dan Ummu Salamah. Muridnya antara lain, Abu Ubaidah bin Abdillah bin Zam'ah, Abdullah bin Zaid, Hamid bin Nafi', Abdullah bin Abd. al-Rahman bin Auf, dan Urwah bin al-Zubair. Pernyataan ulama Hadis terhadap ke-tsiqahan-nya, adalah para ulama 
telah bersepakat bahwa Zainab adalah seorang sahabat yang tidak diragukan lagi kredibilitasnya.

6. Ummu Salamah

Ummu Salamah nama aslinya adalah Hindun binti Abi Umayyah bin al-Mughirah adalah Sahabat Rasulullah Saw, mempunyai nama panggilan (kunyah) Ummu Salamah dan julukannya (Alqab) Ummu al-Mu'minin, menetapa di Madinah wafat pada tahun $62 \mathrm{H}$.

Guru-gurunya adalah Abdullah bin Abd. al-Asad bin Hilal, Fatimah binti Rasulullah Saw, Ja'far bin Abi Thallib bin Abd al-Muthallib bin Hasyim dan Ummi Sulaim. Muridnya antara lain Umamah Walidah Muhammad bin Zaid, Ibrahim bin Abd. al-Rahman bin Abdillah bin Abi Rabi'ah, Abu Bakr bin Abd. al-Rahman bin al-Harits bin Hasyim bin alMughirah, Abnu Iyadh, Abu Katsir Mawla Ummu Salamah, Aslam bin Zaid, al-Aswad bin Yazid bin Qais, Ummu Muhammad bin Qais, Ummu Miswar dan Zainab binti Abi Salamah $^{13}$.

Selanjutnya dalam kegiatan penelitian matan ulama menempuh dengan cara yang berbeda-beda dengan tolok ukur yang berbeda pula. Berkenaan dengan ini, maka penelitian ini merujuk pada rumusan yang ditetapkan oleh Salahuddin al-Adlabi dan al-Khatib alBagdadi bahwa matan suatu hadis dianggap shahih apabila sanad nya shahih; tidak bertentangan dengan al-Qur'an, dan Hadis dan hadis shahih pada matan tersebut tidak terdapat ziyadah yang rancu bahasanya. ${ }^{14}$

Berdasarkan hasil takhrij hadis tersebut dari semua jalur sanad yang ada dapat diketahui bahwa semuanya berstatus hadis marfu', karena semua Sahabat ( sanad terakhirnya) menyandarkan kepada Nabi saw dengan menyatakan :

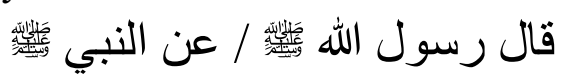

Para perawi hadis di atas memiliki ketersambungan sanad, dengan kata lain sanadnya adalah mutasshil, karena masing-masing dari mereka memiliki sifat yang terpuji, yakni tsiqah, hafizh, tsubut, min al-Hafizh al-Muttaqin dan sifat terpuji lainnya ${ }^{15}$, sehingga dapat dinyatakan bahwa hadisnya dapat diterima. Karena sanad hadis tersebut marfu',mutashil (bersambung) dan dari segi periwayatannya adalah maqbul. Sehingga dapat disimpulkan bahwa hadits tersebut adalah Shahih.

\footnotetext{
${ }^{13}$ Ibnu Hajar al-Asqalani, Tahdzib al-Tahdzib, (Beirut: Qahirah, tt), h. 427.

${ }^{14}$ Salahuddin bin Ahmad al-Adlabi, Manhaj al-Naqd al-Matn ( Bairut, Dar al-Afaq al-Jadidah, 1983), h. 236 .

${ }^{15}$ Ibnu Hajar al-Asqalany, Tahdzib al-Tahdzib, (Beirut: Qahirah, tt), h. 427.
} 


\section{Mufradat al-Hadits}

إِنَّ اللََّ sesungguhnya Allah, kata إنّ adalah salah satu huruf nasab yang berfungsi untuk menasabkan isim dan merafa'kan khabar, kata ini digunakan untuk menguatkan kalimat yang sudah ada sesudahnya karena salah satu arti huruf tersebut adalah " sesungguhnya”. Sedangkan lafaz الله para ulama dan pakar bahasa berbeda pendapat, sebagian besar ulama berpendapat bahwa nama itu Musytaq, (pecahan dari kata lain). Meskipun begitu mereka lalu berbeda pada akar katanya. Sibwaih meriwayatkan pendapat al-Khalil bahwa akar kata lafaz tersebut adalah الاء yang sewazan dengan pola " فعل dimasukkan mengganti huruf hamzah sehingga terbentuk lafzh الله pendapat ini menegaskan bahwa kata tersebut berasal dari kata yang kemudian dimasukkan partikel alif lam dengan makna تعظيم (mengagungkan ), di antara ada yang berpendapat bahwa lafazh tersebut berasal dari kata (إلـ ) yang berarti penyembahan, dikatakan demikian karena sesungguhnya Allah adalah

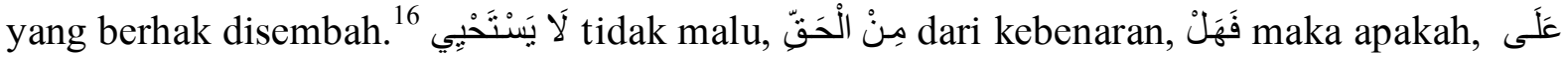

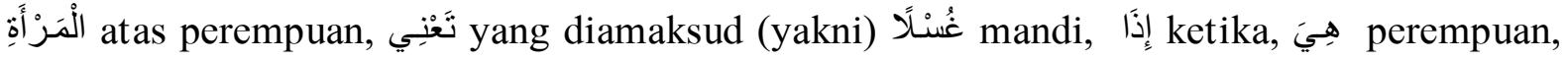

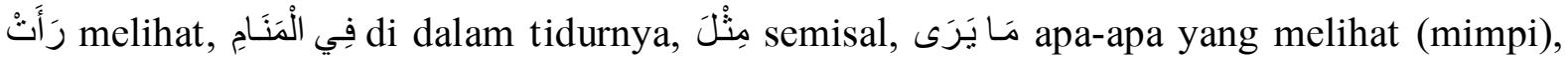

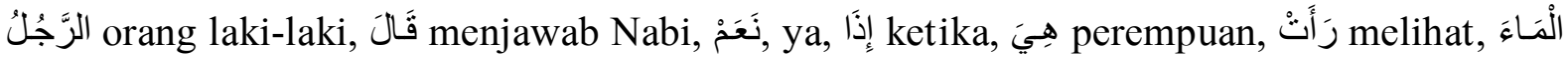
air, فَلْنَنَنَسِـن yang artinya, maka mandilah, kata ini adalah fiil amr (kalimat perintah), berdasarkan kaidah ushul yang menyatakan bahwa setiap kalimat yang mengandung

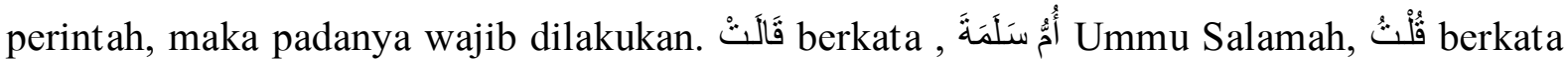

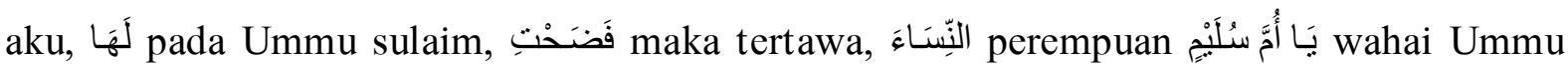
Sulaim

\section{Sebab-sebab periwayatan Hadis / al-Asbab al-Wurud}

Asbab al-Wurud al-hadits adalah sebab-sabab hadits tersebut diriwayatkan yaitu tentang perempuan juga bisa mengalami mimpi basah dan mengeluarkan mani sebagaimana halnya laki-laki. Ummu Sulaim datang kepada Nabi SAW dan bertanya, :

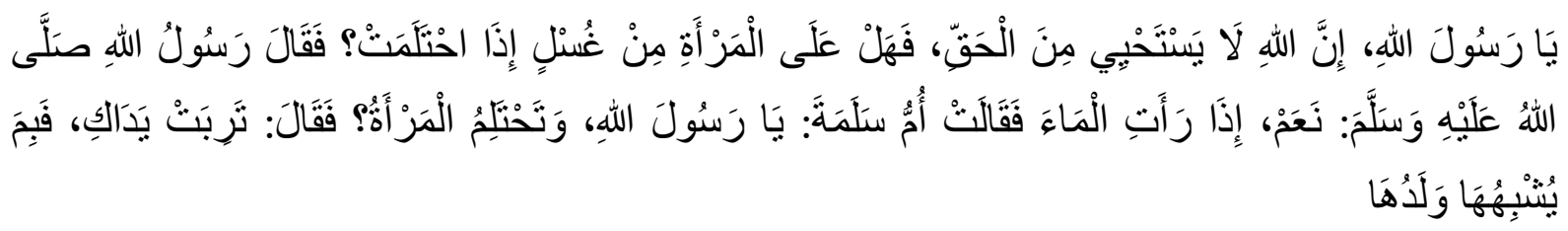

Terjemahnya :

Wahai Rasulullah, sesungguhnya Allah tidak malu dalam menjelaskan kebenaran, "Apakah wanita wajib mandi jika mimpi basah (mengeluarkan mani)?" Nabi SAW 86.

\footnotetext{
${ }^{16}$ Ahmad ibn Fariz ibn Zakariyah, al-Mu’jam al-Muqayyis Fi al-lughah ( Bairut, Dar al-Fikr, 1994), h.
} 
menjawab: "Ya, apabila wanita melihat air mani" Ummul Mukminin Ummu Salamah (yang waktu itu berada di sampingnya) bertanya, "Apakah wanita juga mimpi basah?" Nabi SAW menjawab: "Bagaimana kamu, dari mana seorang anak bisa mirip dengan ibunya ? (kalaupun bukan karena mani tersebut).

Maka berdasarkan pertanyaannya Ummu Sulaiam ini secara implisit ditemukan asbab al-Wurud hadis ini.

\section{Syarah Hadits}

Dari hadis yang diteliti bisa disimpulkan bahwa lelaki maupun wanita yang mimpi basah kemudian mengeluarkan mani maka dia wajib mandi. Sebaliknya, jika tidak mengeluarkan mani maka tidak wajib mandi, karena yang menjadi acuan mandinya adalah keluarnya mani, bukan mimpinya. Jika mimpi itu telah berlalu lama sekali dan keluar air, maka ia wajib mandi ketika mengingatnya dan menghitung berapa shalat yang telah ia tinggalkan kemudian menggantinya.

Ulama sepakat tentang wajibnya seseorang mandi bila mengeluarkan mani, dan tidak ada perbedaan di sisi kami apakah keluarnya karena jima' (senggama), ihtilam (mimpi basah),onani, atau melihat sesuatu yang membangkitkan syahwat. Sama saja, apakah keluarnya dengan syahwat atau pun tidak, dengan rasa nikmat atau tidak, banyak atau pun sedikit walaupun hanya setetes, dan sama saja apakah keluarnya di waktu tidur atau pun ketika tidak tidur, baik laki-laki maupun wanita. ${ }^{17 "}$ Namun maninya laki-laki berbeda dengan maninya perempuan, Mani laki-laki itu kental dan berwarna putih sedangkan mani wanita tipis/halus dan berwarna kuning

Imam al-Nawawi dalam Syarah Muslim mengatakan :

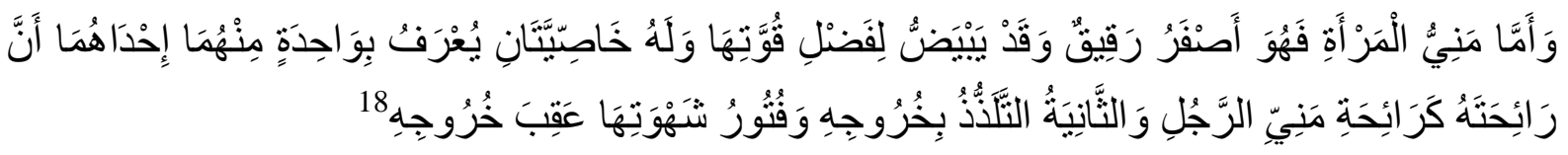

Artinya :

Adapun mani wanita maka dia berwarna kuning, tipis/halus. Namun, terkadang warnanya bisa memutih karena kelebihan kekuatannya. Mani wanita ini bisa ditandai dengan salah dari dua hal : pertama, aromanya seperti aroma mani laki-laki dan kedua, terasa nikmat ketika keluarnya dan meredanya syahwat setelah mani keluar.

Selanjutnya dalam al-Majmu' Syarah al-Muhazzab, Imam al-Nawawi mengatakan :

${ }^{17}$ al-Nawawi, Majmu' Syarah al-Muhazzab, Juz. II, (Jeddah: Maktabah al-Irsyad, tt), h. 239.

${ }^{18}$ Al-Nawawi, Syarah Muslim, Juz, III, (Jedah: Muassasah Qurthubah, tt), h. 287. 


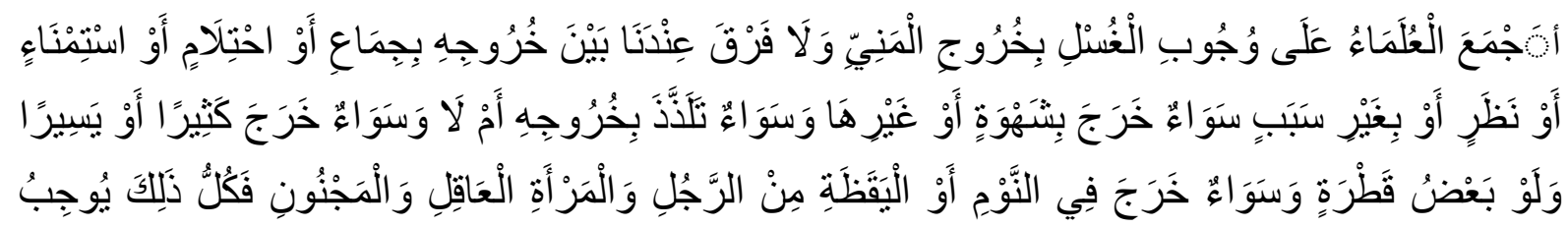

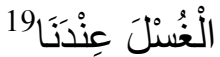

Artinya :

Telah terjadi ijmak ulama wajib mandi bila seseorang mengeluarkan mani, dan tidak ada perbedaan di sisi kita apakah keluarnya karena jima', ihtilam (mimpi basah),onani, atau melihat sesuatu yang membangkitkan syahwat atau tanpa sebab. Sama saja, apakah keluarnya dengan syahwat ataupun tidak, dengan rasa nikmat atau tidak, banyak ataupun sedikit walaupun hanya setetes, dan sama saja apakah keluarnya di waktu tidur ataupun ketika tidak tidur, baik laki-laki maupun perempuan, yang berakal atau gila, semua hal itu mewajibkan mandi di sisi kita.

Memang benar diantara salah satu tanda seseorang akil baligh bagi wanita adalah keluarnya darah haidh dan bagi laki-laki mimpi basah. Hal ini menunjukkan bahwa mimpi basah banyak dialami oleh kaum Adam (laki-laki). Namun perempuan juga ada yang mengalami mimpi basah sesuai dengan hadits diatas.

\section{Fikih Hadis}

1. Hadis ini adalah salah satu dalil yang menjelaskan tentang tata cara mandi wajib bagi wanita ketika mimpi basah.

2. Seseorang tidak boleh malu untuk bertanya sesuatu hal yang belum diketahuinya agar mendapat penjelasan yang benar.

3. Tanya jawab adalah salah satu metode pendidikan yang dapat memudahkan proses transformasi ilmu pengetahuan.

\section{PENUTUP}

Dari hadis di atas juga bisa disimpulkan bahwa lelaki maupun wanita yang mimpi basah kemudian mengeluarkan mani maka dia wajib mandi. Sebaliknya, jika tidak mengeluarkan mani maka tidak wajib mandi, karena yang menjadi acuan mandinya adalah keluarnya mani, bukan mimpinya. Ulama sepakat tentang wajibnya seseorang mandi bila mengeluarkan mani, dan tidak ada perbedaan di sisi kami apakah keluarnya karena jima'(senggama), ihtilam (mimpi basah), onani, atau melihat sesuatu yang membangkitkan syahwat. Sama saja, apakah keluarnya dengan syahwat atau pun tidak, dengan rasa nikmat atau tidak, banyak atau pun sedikit walaupun hanya setetes, dan sama saja apakah keluarnya di waktu tidur atau pun ketika tidak tiduran, baik laki-laki maupun

${ }^{19}$ al-Nawawi, Majmu’ Syarah al-Muhazzab, Juz. II, (Jeddah: Maktabah al-Irsyad, tt), h. 158. 
wanita." Namun maninya laki-laki berbeda dengan maninya perempuan, Mani laki-laki itu kental dan berwarna putih sedangkan mani wanita tipis/halus dan berwarna kuning

Pada kegiatan takhrij al-hadis dalam artikel ini penulis memilih menggunakan metode penelusuran melalui lafaz-lafaz yang terdapat dalam matan hadis dengan alat bantu “al-Mu'jam al-Mufahras li al-lafzh al-Hadits al-Nabawi” dengan menelusuri kata-kata غسل, berdasarkan penelurusan tersebut diperoleh data bahwa hadis tersebut di Takhrij oleh tujuh mukharrijl akhrijahu al-Sab'ah dengan 14 jalur sanad dan sahabat yang meriwayatkan dari nabi ada 6 yaitu; Aba Salamah, Ummi Salamah, Ummi Sulaim, Zainab binti Aba Salamah, dan Aisyah.

Selanjutnya dalam kegiatan penelitian matan ulama menempuh dengan cara yang berbeda-beda dengan tolok ukur yang berbeda pula. Berkenaan dengan ini, maka penelitian ini merujuk pada rumusan yang ditetapkan oleh Salahuddin al-Adlabi dan al-Khatib alBagdadi bahwa matan suatu hadis dianggap shahih apabila sanad nya shahih; tidak bertentangan dengan al-Qur' an, dan hadis shahih pada matan tersebut tidak terdapat ziyadah yang rancu bahasanya.

Para perawi hadis di atas memiliki ketersambungan sanad, dengan kata lain sanadnya adalah mutasshil, karena masing-masing dari mereka memiliki sifat yang terpuji, yakni tsiqah, hafizh, tsubut, min al-Hafizh al-Muttaqin dan sifat terpuji lainnya, sehingga dapat dinyatakan bahwa hadisnya dapat diterima. Karena sanad hadis tersebut marfu',mutashil (bersambung) dengan sanad ahad dan dari segi periwayatannya adalah maqbul. Sehingga dapat disimpulkan bahwa hadits tersebut adalah Shahih. 


\section{DAFTAR PUSTAKA}

Abi 'Abdillah Muhammad bin Isma'il bin Ibrahim bin Mughirah bin Bardizbah al-Bukhari al-Ju'fiy, Juz. I, V, Semarang, Karya Toha Putera, tt.

Abi 'isa Muhammad ibn Aisay ibn Surah al-Tarmizy, Sunan al-Tarmizy, Beirut-Libanon, Dar al-Kotob al-Ilmiyah, 2003M-1324H.

Abu Abdillah bin Abd. al-Rahman bin al-Tamimiy al-Dzarimiy, Sunan al-Darimi alSamarqaniy, Juz. I Bandung, Dahlan, tt.

Ahmad al-Adhabi, Shalah al-Din, Manhaj al-Naql al-Matn al-Hadis, Cet. II; Kairo: Dar alAfaq al-Jadidah, 1983.

Ahmad bin Hanbal, Syarah Hamzah Ahmad Zain, Musnad Ahmad bin Hanbal, Juz. 7, 8, 9 al-Qahirah, Dar al-Hadits, 1999.

Ahmad ibn Fariz ibn Zakariyah, al-Mu'jam al-Muqayyis Fi al-lughah Bairut, Dar al-Fikr, 1994.

Al-Nawawi, Majmu’ Syarah al-Muhazzab, Juz. II, Jeddah: Maktabah al-Irsyad, tt.

Al-Nawawi, Syarah Muslim, Juz, III, Jedah: Muassasah Qurthubah, tt.

Arief Halim, M, Metodelogi Tahqiq Hadith Secara Mudah dan Munasabah Pulau Pinang, Universiti Sains Malaysia, 2007), h.42. Lihat juga M. Syuhudi Ismail, Metodelogi Penelitian Hadis, Cet. I, Jakarta, Bulan Bintang, 1992.

Arnold John Wensinck, et, al, Concordance et Indices De Ela Tradition Musulmane, diterjemahkan ke dalam bahasa Arab oleh Muhammad Abd. Fu'ad Baqy, dengan judul al-Mu'jam al-Mufahras Li alfazh al-Hadits al-Nabawi, Jilid. I Leiden, E. J. Brill, 1946.

Ibnu Hajar al-Asqalany, Tahdzib al-Tahdzib, Beirut: Qahirah, tt.

Jalauddin al-Suyuti, Sunan al-Nasa'iy, Beirut Dar al-Kitab al-Araby, tt.

Muhammad Fu'ad 'Abdu al-Baqy, Shahih Muslim, Juz. II Beirut, al-Ahyar al-Tarits al'Arabiy).

Mustafa al-Azami, Dirasah fi al-Hadis al-Nabawi; Tarikh tadwinihi, Riyad, Jamiah Riyad, tt.

Salahuddin bin Ahmad al-Adlabi, Manhaj al-Naqd al-Matn Bairut, Dar al-Afaq al-Jadidah, 1983.

Shiddiqiy Jamil al-'Atthar, al-Mu'attha’Beirut Dar-al-KOTTOB, 2002. 